$\mathrm{DOI}$

\title{
АНАЛІЗ АНАМНЕСТИЧНИХ ТА ЛАБОРАТОРНИХ ПОКАЗНИКІВ ПАЦІЄНТОК 3 ГІПЕРПЛАСТИЧНИМИ ПРОЦЕСАМИ ЕНДОМЕТРІЯ ЗА ДОПОМОГОЮ БАГАТОПАРАМЕТРИЧНОЇ НЕЙРОМЕРЕЖЕВОЇ КЛАСТЕРИЗАЦІї
}

\author{
ФА. Ф. Слива, П. Р. Сельський, Б. П. Сельський \\ ДВНЗ «Тернопільський державний медичний університет імені І. Я. Горбачевського МОЗ України»
}

\begin{abstract}
РЕЗЮМЕ. 3 метою підвищення ефективності діагностики гіперпластичних процесів ендометрія у жінок перименопаузального віку було проведено ретроспективний аналіз 52 карт стаціонарного хворого жінок, які перебували на лікуванні в гінекологічних відділеннях Тернополя і області. У відповідності з патогістологічним висновком, 1 групу склали 28 жінок з простою гіперплазією ендометрія, 2 групу - 24 жінки з комплексною гіперплазією ендометрія. У групу порівняння ввійшли 12 соматично здорових жінок. Пересічний вік хворих 1 групи становив $(47,0 \pm 1,0)$ років, 2 групи - $(56,0 \pm 1,5)$ років. 3 метою поглибленого аналізу показників застосовано багатопараметричну нейромережеву кластеризацію.

Встановлено, що до факторів ризику розвитку гіперпластичних процесів ендометрія у жінок перименопаузального періоду належать неблагополучні соціально-економічні фактори: проживання в сільській місцевості, тяжкі умови праці, шкідливі звички та обтяжений акушерсько-гінекологічний анамнез, 3 і більше вагітностей, велика кількість (4 і більше) акушерсько-гінекологічних втручань, використання внутрішньоматкової контрацепції.

3 метою встановлення значення поєднаних змін тих чи інших параметрів для прогнозу прогресування захворювання здійснено нейромережеву кластеризацію. Встановлено, що ймовірність прогресування гіперпластичних процесів ендометрія зростає з віком, якщо це поєднується із збільшенням кількості лейкоцитів у периферійній крові.
\end{abstract}

КЛЮчОВІ СЛОВА: гіперпластичні процеси ендометрія, перименопаузальний вік, проста гіперплазія ендометрія, комплексна гіперплазія ендометрія, прогресування захворювання, нейромережева кластеризація.

Вступ. Частота гіперпластичних процесів ендометрія за останні 10 років зросла з 2,1 до 3,8\%. Зазначену патологію діагностують у $46 \%$ жінок пізнього репродуктивного та пременопаузального віку. Водночас до половини випадків раку едометрія в пременопаузі виникає саме внаслідок малігнізації гіперпластичних процесів ендометрія $[4,7]$. Не зважаючи на велику кількість досліджень етіопатогенезу даних захворювань $[1,2]$, недостатньо вивченими залишаються фактори ризику та вплив супутньої патології на прогресування різних видів гіперплазії у жінок перименопаузального віку. При цьому для підвищення ефективності діагностики, зокрема і гінекологічної патології, у медицині все більшого значення набуває застосування інформаційних технологій [5]. Проте не до кінця вирішеною залишається проблема застосування простих і доступних інформаційних методик, які не потребують значних фінансових затрат.

Мета дослідження. Проаналізувати анамнестичні та лабораторні показники обстеження пацієнток перименопаузального віку з гіперпластичними процесами ендометрія для підвищення ефективності діагностики прогресування захворювання із застосуванням багатопараметричної нейромережевої кластеризації.

Матеріал і методи дослідження. Проведено ретроспективний аналіз 52 карт стаціонарного хворого і біопсій, взятих у жінок перименопау- зального віку, які перебували на обстеженні в гінекологічних відділеннях лікувальних закладів Тернополя та області. Проаналізовано: вік хворих, соціально-економічні фактори, акушерськогінекологічний анамнез у жінок з різними видами гіперплазії.

Патогістологічний діагноз верифікований клінічно та гістологічно з врахуванням класифікації гіперпластичних процесів ендометрія (ГПЕ) BOОЗ 1994 р. [3].

Контрольну групу становили 12 соматично здорових жінок віком $(45,5 \pm 0,7)$ років.

Математичний аналіз даних проведений за допомогою методів варіаційного аналізу. Статистична обробка матеріалу була проведена 3 використанням пакета програм «Microsoft Excel» (Microsoft Office 2003). Статистичну значимість відмінностей між середніми арифметичними і відносними величинами оцінювали за критерієм Стьюдента-Фішера (t).

Для більш глибокого аналізу показників з метою прогнозування перебігу захворювання застосовано нейромережевий підхід з використанням надбудови NeuroXL Classifier для програми Microsoft Excel. Для алгоритму нейромережевої кластеризації обрано параметри, запропоновані програмою, та кількість кластерів, рівну трьом. Програма NeuroXL Classifier (розробка компанії AnalyzerXL) реалізує самоорганізаційні нейромережі, що виконують категоріювання шляхом 
Огляди літератури, оригінальні дослідження, погляд на проблему

вивчення трендів і взаємозв'язків усередині даних. Не зважаючи на високу ефективність, нейромережі часто не використовуються через свою складність і тривале навчання, необхідне для їх правильної реалізації. NeuroXL Classifier усуває такі бар'єри, приховуючи складність методів на основі нейромереж і використовуючи переваги робочих книг Microsoft Excel $[6,8]$.

Результати й обговорення. Ми провели ретроспективний аналіз карт стаціонарного хворого 52 жінок. У відповідності з патогістологічним висновком 1 групу складали 28 жінок з простою гіперплазією ендометрія (ПГЕ), 2 групу - 24 жінки з комплексною гіперплазією ендометрія (КГЕ). Пересічний вік хворих 1 групи становив $(47,0 \pm 0,7)$ років, а 2 групи - $(56,0 \pm 1,2)$ років.

Серед обстежених хворих 2/3 жінок проживали в сільській місцевості. Очевидно, це зумовило низький ступінь звертань до лікувальних закладів та своєчасної профілактики захворювання. $18 \%$ жінок з ПГЕ та майже $21 \%$ з КГЕ вказували на тяжкі чи шкідливі умови праці протягом життя. Шкідливі звички були майже в $11 \%$ та 17 \% хворих 1 та 2 груп відповідно (табл. 1).

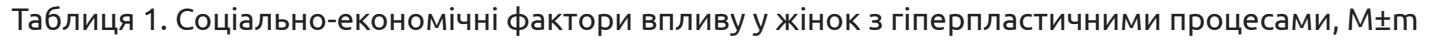

\begin{tabular}{|l|c|c|c|}
\hline \multirow{2}{*}{\multicolumn{1}{c|}{ Критерії }} & \multicolumn{3}{|c|}{ Кількість жінок (\%) } \\
\cline { 2 - 4 } & $\begin{array}{c}\text { ПГЕ } \\
(\mathrm{n}=28)\end{array}$ & $\begin{array}{c}\text { КГЕ } \\
(\mathrm{n}=24)\end{array}$ & $\begin{array}{c}\text { ГП } \\
(\mathrm{n}=12)\end{array}$ \\
\hline Місце проживання & $71,4 \pm 8,7$ & $70,8 \pm 9,5$ & $67,7 \pm 14,2$ \\
\hline Тяжкі умови праці & $17,9 \pm 7,4$ & $20,8 \pm 8,5$ & $8,3 \pm 8,3$ \\
\hline Шкідливі звички & $10,7 \pm 6,0$ & $16,7 \pm 7,8$ & $8,3 \pm 8,3$ \\
\hline
\end{tabular}

Проаналізувавши дані анамнезу ми встановили, що майже в половини жінок було більше трьох вагітностей, що в 2,5 раза більше, ніж у групі порівняння. Кількість перенесених акушерсько-гінекологічних втручань та відсоток вико- ристання внутрішньоматкової контрацепції був достовірно $(P<0,05)$ вищим у жінок з ПГЕ та КГЕ, порівняно з пацієнтками без гіперплазії. Безпліддя виявлено у 2 жінок $((7,14 \pm 5,0) \%) 1$ групи та 1 жінки $((4,17 \pm 4,17) \%) 2$ групи (табл. 2).

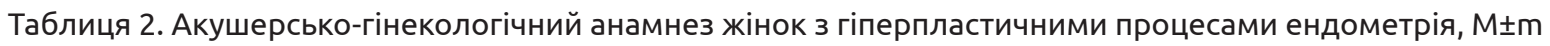

\begin{tabular}{|l|c|c|c|}
\hline \multirow{2}{*}{\multicolumn{1}{|c|}{ Критерії }} & \multicolumn{3}{c|}{ Кількість жінок (\%) } \\
\cline { 2 - 4 } & $\begin{array}{c}\text { ПГЕ } \\
(\mathrm{n}=28)\end{array}$ & $\begin{array}{c}\text { КГЕ } \\
(\mathrm{n}=24)\end{array}$ & $\begin{array}{c}\text { ГП } \\
(\mathrm{n}=12)\end{array}$ \\
\hline Кількість вагітностей $\leq 3$ & $42,9 \pm 9,5$ & $45,8 \pm 10,4$ & $16,7 \pm 11,2$ \\
\hline Кількість акушерсько-гінекологічних втручань $\leq 4$ & $60,7 \pm 9,4$ & $62,5 \pm 10,1$ & $\begin{array}{c}25,0 \pm 13,1 \\
\mathrm{P}_{1-3}<0,05 \\
\mathrm{P}_{2-3}<0,05\end{array}$ \\
\hline Внутрішньоматкова контрацепція & & & $8,3 \pm 8,3$ \\
& & $37,5 \pm 10,1$ & $\mathrm{P}_{2-3}^{<0,05}$ \\
\hline Безпліддя & $21,4 \pm 7,9$ & & 0 \\
\hline
\end{tabular}

3 метою встановлення значення поєднаних змін тих чи інших параметрів для прогнозу прогресування захворювання здійснено нейромережеву кластеризацію на основі таких анамнестичних та лабораторних показників пацієнток: Age - вік, Res - місце проживання (місто/село), Preg - вагітність, Орег - кількість перенесених акушерсько-гінекологічних втручань, W - умови праці (нешкідливі/шкідливі), Bhab - шкідливі звички, Sp - внутрішньоматкова спіраль, Hb - гемоглобін, Ег - еритроцити, L - лейкоцити та ESR швидкість осідання еритроцитів.

Обрані три кластери. На рисунках 1 та 2 наведено деякі результати виконання програми для пацієнтів з ГПЕ. Показник форми захворювання (F) фіксували навпроти кожного хворого як «1» при ПГЕ та «2» у випадку КГЕ. У 2 кластер включені лише пацієнтки із КГЕ (100\%). Водночас, у 3 кластері частка хворих із КГЕ складала 73,3 \%, а у 1 - таких пацієнток не виявлялось. При цьому кількість жінок із КГЕ також була найбільшою у 2-ому кластері (2 кластер - 13 пацієнток, 3 - 11 пацієнток). За допомогою кластерного портрета (рис. 2) можна визначити, що на 2 кластер, поряд із найвищим значенням «F», припадають і вищі показники віку (Age) та кількості лейкоцитів у периферійній крові (L). При цьому інші показники у даному кластері не перевищували аналогічні 1 та 3 кластерів.

Порівняльний аналіз пересічних значень відносних та пересічних показників $\epsilon$ первинним інструментом, який не дає змогу встановити значен- 
Огляди літератури, оригінальні дослідження, погляд на проблему

ня поєднання зміни тих чи інших параметрів для

поєднання вікового показника та показника рівня прогнозування прогресування захворювання. Водлейкоцитів крові дає підставу прогнозувати більночас, аналіз кластерних портретів показав, що ший ризик розвитку КГЕ у обстежених пацієнток.

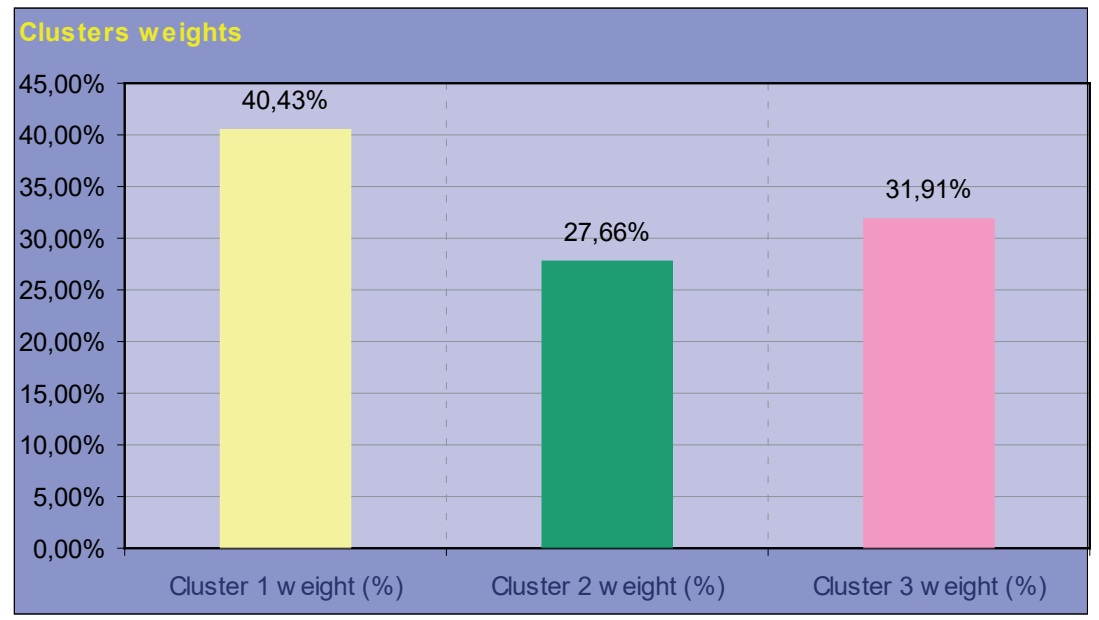

Рис. 1. Частки кластерів - відсотки пацієнток, які потрапили у певний кластер.

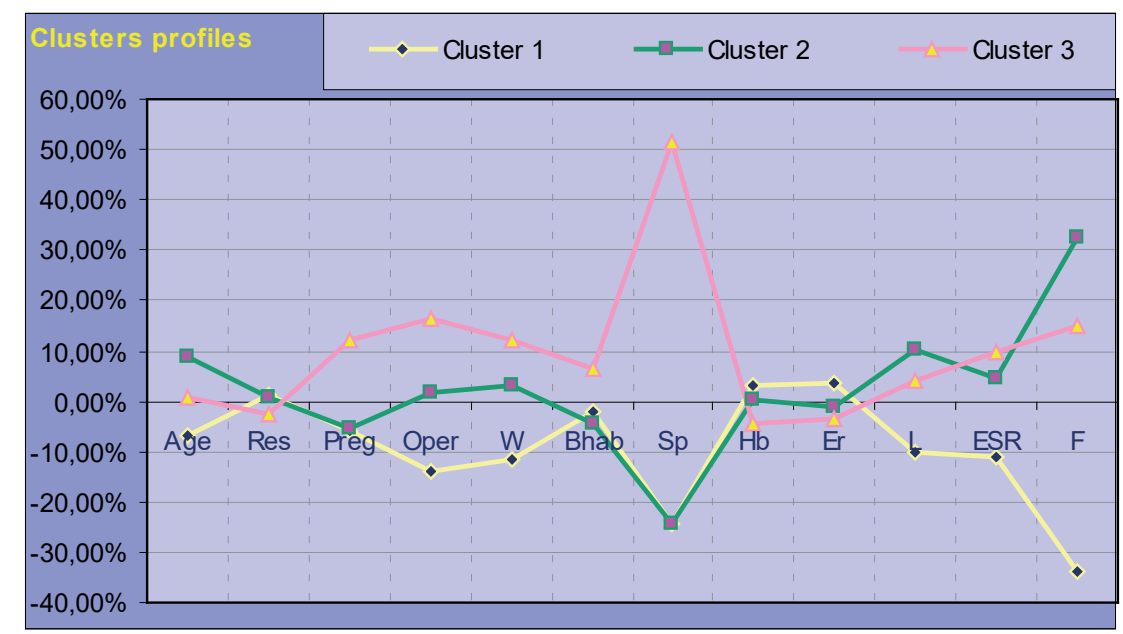

Рис. 2. Кластерний портрет - значення параметрів в межах розподілених кластерів.

Висновки. До факторів ризику розвитку гіперпластичних процесів ендометрія жінок у перименопаузальному періоді належать неблагополучні соціально-економічні фактори: проживання в сільській місцевості, тяжкі умови праці та шкідливі звички.

Гіперпластичні процеси ендометрія достовірно частіше розвиваються у жінок з хронічними захворюваннями матки, трьома і більше вагітностями, великою кількістю (4 і більше) акушерськогінекологічних втручань та використанням внутрішньоматкової контрацепції в анамнезі.

За допомогою багатопараметричної нейромережевої кластеризації встановлено, що ймо- вірність прогресування гіперпластичних процесів ендометрія зростає з віком, якщо це поєднується із збільшенням кількості лейкоцитів у периферійній крові.

Перспективи подальших досліджень. Перспективним $\epsilon$ використання результатів виявлених закономірностей на основі анамнестичного аналізу та аналізу змін лабораторних показників із використанням багатопараметричної нейромережевої кластеризації для подальших досліджень щодо розробки діагностичних критеріїв прогнозування прогресування захворювань у регіоні. 
Огляди літератури, оригінальні дослідження, погляд на проблему

\section{ЛІТЕРАТУРА}

1. Вихляева Е. М. Гиперпластические процессы эндометрия / Е. М. Вихляева, Б. И. Железное, В. Н. Запорожан // Руководство по эндокринной гинекологии. М. : МИА, 2002. - С. 603-710.

2. Волкова Н. И. Здоровье женщин в перименопаузе. Теория и практика / Н. И. Волкова // Жур. акуш. и жен. болезней. 2004. - Вып. 2, T. LII. - C. 54-59.

3. Кузнецов И. В. Гиперпластические процессы эндометрия / И. В. Кузнецов. - М. : Медицина, 2009. - 48 с.

4. Климактерический период и менопауза // Рациональная фармакотерапия в акушерстве и гинекологии : руководство для практ. вр. - М., 2005. - Гл. 48. С. $593-603$.

5. Концепція інформатизації охорони здоров'я України / О. П. Мінцер, Ю. В. Вороненко, Л. Ю. Бабінцева [та ін.] // Медична інформатика та інженерія. - 2012. № 3. - С. 5-29.
6. Марценюк В. П. Нейромережеве прогнозування складання студентами-медиками ліцензійного інтегрованого іспиту "Крок 1" на основі результатів поточної успішності та семестрового комплексного тестового іспиту / В. П. Марценюк, А. В. Семенець, О. О. Стаханська // Медична інформатика та інженерія. - 2010. № 2. - C. 57-62.

7. Metabolic and vascular effect of progestins in postmenopausal women: implications for cardioprotection / G. M. C. Rosano, C. Vitale, A. Silvestri, M. Fini // Maturitas. 2003. - Vol. 46 (Suppl. 1). - P. 17-29.

8. Shepherd A. J. Second-Order Methods for Neural Networks : Fast and Reliable Training Methods for MultiLayer Perceptrons / A. J. Shepherd. - London : Springer, 1997. - 342 p.

\title{
ANALYSIS OF MEDICAL HISTORY AND LABORATORY PARAMETERS OF PATIENTS WITH ENDOMETRIAL HYPERPLASTIC PROCESSES USING MULTI-PARAMETER NEURAL NETWORC CLUSTERING
}

\author{
@A. F. Slyva, P. R. Selskyi, B. P. Selskyi \\ I. Horbachevsky Ternopil State Medical University
}

SUMMARY. To improve the efficiency of diagnosis of endometrial hyperplastic processes in perimenopausal women was conducted a retrospective analysis of 52 cards inpatient women who were treated at gynecological departments of Ternopil region. According to the histopathological finding 1st group included 28 women with simple endometrial hyperplasia; 2 nd group - 24 women with complex endometrial hyperplasia. Comparison group consisted of 12 somatically healthy women. The average age of patients of group $1-(47.0 \pm 1.0)$ years, group $2-(56.0 \pm 1.5)$ years. In order depth analysis parameters neural network clustering applied.

Established that the risk factors for hyperplastic processes of endometrium in women of perimenopausal period include disadvantaged socio-economic factors: residence in rural areas, difficult working conditions, bad habits and burdened obstetric and gynecological history, 3 or more pregnancies, a large number (4 and more) obstetrical interventions, use of intrauterine contraception.

In order to determine the value of the combined changes of various parameters for the prediction of disease progression implemented neural network clustering. It is found that the likelihood of the progression of endometrial hyperplasia increases with age, if it is combined with the number of leukocytes in peripheral blood.

KEY WORDS: endometrial hyperplasia, perimenopausal age, simple endometrial hyperplasia, complex endometrial hyperplasia, disease progression, clustering neural network. 